\title{
Detection of HPV DNA Using MY09/MY11 and G5/G6 Primer Sets in HIV Positive Patients with Positive Linear Array Genotype Assay Results
}

\author{
Vinay. P. S ${ }^{1}$, Chidanand Patil ${ }^{1}$, Mahantesh Nagmoti ${ }^{2}$, Anita Dalal ${ }^{3}$, Shivalingappa Javali ${ }^{4}$ \\ 1Department of Microbiology, USM-KLE IMP, Belagavi, India. \\ 2Department of Microbiology, JN Medical College, KLE University, Belagavi, India. \\ 3Department of OBG, JN Medical College, KLE University, Belagavi, India. \\ ${ }^{4}$ Department of Community medicine, USM-KLE IMP, Belagavi, India.
}

\begin{abstract}
Introduction: Human papillomavirus (HPV) is identified as the primary agent of cervical cancer and is the most common sexually transmitted disease in women especially in HIV infected women. Many studies have shown that Polymerase chain reaction (PCR) is the most sensitive method for the detection of HPV cervical samples as compared to conventional methods of detection of HPV infections.

Objective: This study aimed to compare the detection by of human papillomavirus (HPV) DNA in cervical specimens by using two different primers MY09/11 and G5/G6.

Methods: Two hundred and fourteen women who came to the department of Obstetrics and gynecology were enrolled in the study. In the first step all 214 samples were tested for the presence of HPV by Roche Linear array (RLA) genotype assay and thirty three samples which was positive for HPV in RLA were further tested for HPV DNA by using 2 different primers.

Results: From the 33 samples which were positive in RLA, HPV DNA was detected in $63.7 \%$ (21 of 33 ) and $72.73 \%$ (24 of 33) of the samples by using the MY09/11 and the G5/G6 primer sets, respectively. Among the $24 \mathrm{HPV}$-positive samples, $21(63.7 \%)$ were detected by one or both methods and 3
\end{abstract}

\section{INTRODUCTION}

Cervical carcinoma is the fourth most common cancer of women worldwide which is due to Human papillomavirus infection. Current estimate indicate that 520000 new cases are diagnosed every year and more than 270000 deaths occur from this disease, more than $85 \%$ of these deaths are reported from less developed regions ${ }^{1}$. These estimates represent $7.5 \%$ of all female deaths due to cancer. The majority of cases are squamous cell carcinoma followed by adenocarcinomas ${ }^{2-5}$.

Human papillomaviruses (HPV) belongs to DNA viruses whcih infect cutaneous, mucocutaneous and mucosal epithelial cells of human beings which most commonly causes subclinical infections without physical symptoms. Until now, more than $170 \mathrm{HPV}$ genotypes have been identified 6 and these are characterized on the basis of the study of complete genomes, and the data shows that a larger number of unidentified genotypes still exists ${ }^{7}$. Out of this more than 45 types of which gets typically transmitted through sexual contact which infect the anogenital region
$(9.09 \%)$ were detected only by G5/G6 primer set.

Conclusion: This study suggests that more than one type of oligonucleotide primers should be used in clinical samples to increase sensitivity for the detection of HPV.

Key words: Cervical cancer, RLA, HPV-PCR, MY09/11, G5/G6.

\section{${ }^{*}$ Correspondence to:}

Vinay. P. S

Senior Lecturer, Microbiology

USM-KLE International Medical Programme,

Nehru Nagar, Belagavi, Karnataka, India.

\section{Article History:}

Received: 01-08-2016, Revised: 07-08-2016, Accepted: 27-08-2016

\begin{tabular}{|l|c|}
\hline \multicolumn{2}{|c|}{ Access this article online } \\
\hline Website: & Quick Response code \\
www.ijmrp.com & \\
\hline DOI: & \\
10.21276/ijmrp.2016.2.5.005 & \\
\hline
\end{tabular}

(anus and genitals) and mucosal regions ${ }^{8}$. These mucosal types have been further classified into 2 categories as High risk types $(16,18,31,33,35,39,45,51,52,56,58,59,68,73$, and 82$)$, and low-risk HPV types $(6,11,40,42,43,44$, and 70$) .{ }^{9}$ It has been proved by several studies that infection with certain types of the human papillomavirus (HPV) is the primary risk factor for cervical cancer and its precursor lesions ${ }^{10,11}$ and it has been shown that high risk HPV types are most commonly associated with several malignant diseases, of which cervical cancer is of prime significance. High risk HPV type DNA has been detected in $99.7 \%$ of cervical cancer tissue specimens ${ }^{12}$, and also the persistent infections with an oncogenic HPV type, particularly HPV type 16 (HPV-16) or HPV-18, are recognized as an important cause of cervical cancer.

Several studies have shown that human papillomavirus (HPV) infection rate is higher in human immunodeficiency virus (HIV) infected women than HIV uninfected women, and these HIV 
infected women are also at higher risk for persistent infection and further progression to malignancy ${ }^{13-16}$. In addition to this few studies have shown that HPV may be a cofactor in HIV acquisition 17,18 .

Many studies have shown that HPV genotyping is of importance for the study of the natural history of infections with one or multiple HPV types and their role in persistence and progression of cervical lesions and also for the monitoring of success of vaccination and vaccine efficacy.

In developed countries, several screening programmes are in place which enables women to get screened regularly, making most of the pre-cancerous lesions identifiable at early stages which can easily be treated so as it can be prevented in approximately $80 \%$ of cases.

In developing countries, due to lack of access to effective screening methods and lack of awareness among the people, these diseases are often not identified until it is further advanced and further symptoms are developed. In addition, this makes prospects for treatment of such late-stage disease poor which results in a higher incidence of death from cervical cancer.

The high mortality rate from cervical cancer globally (52\%) could be reduced by effective screening and treatment programmes ${ }^{19}$.

Even though HPV infection can be detected by preventive examinations like a Pap smear test, or pathological test by colposcopy directed cervical biopsy, this is often not possible due to its less sensitivity and specificity. However, the presence of HPV can be confirmed with high accuracy in terms of high sensitivity and specificity, by identifying the viral genome present in cervical lesions by molecular methods ${ }^{20}$.

Currently there are several techniques available for the molecular diagnosis of HPV, ranging from a conventional Polymerase Chain Reaction (PCR) to complex methods, such as real-time PCR, hybrid capture assay(HC2), cobas HPV test, Roche linear array ${ }^{21,22}$. The PCR technique is still considered the most reliable method for HPV diagnosis due to its simplicity and cost effectiveness as compared to high throughput sequencing tests which are in a way more expensive.

The PCR system commonly uses MY09/MY11 and G5/G6 primers that amplify the $L 1$ region of viral genome. These primers are effective for amplifying a wide spectrum of HPV genotypes in cells obtained from cervical smears. The MY09-MY11 primer set is synthesized with several degenerate nucleotides in each primer and is thus a mixture of 25 primers with approximately $450 \mathrm{bp}^{23,24}$. The GP5+-GP6+ primer set consists of a fixed nucleotide sequence for each primer with approximately $150 \mathrm{bp}$ and detects a wide range of HPV types by using a lowered annealing temperature during $\mathrm{PCR}^{24}$. Several studies indicate that testing for HPV by any single method or technique may not give the true prevalence of HPV in cervical samples ${ }^{25,26}$. This study aimed to investigate HPV infection in HIV infected women with positive PCR-RLA assay results, to verify the performance of MY09/ MY11 and G5/G6 primer sets for HPV detection.

\section{METHODS}

\section{Study population}

This is a cross-sectional study of 214 HIV-infected women aged from 18- 45 years, attending department of Obstetrics \& Gynecology at KLE's Prabhakar Kore hospital and medical research center, Belagavi, India. The study was approved by the human research ethics committee of the KLE University, Belagavi, India in June 2013, and informed consent was obtained from all the study participants after providing the study fact sheet.

\section{Sample collection and methods}

Cervical sample were collected from the transformation zone of the cervix using the DNA collection device (cytobrush) which were rinsed in $20 \mathrm{ml}$ of PreservCyt $₫$ vial (Hologic, Inc.). Samples were immediately stored at $4^{\circ} \mathrm{C}$ and transported to the laboratory at the department of Microbiology where they were further stored at $20^{\circ} \mathrm{C}$ until DNA extraction. Simultaneously, data collection, clinical examination, Papanicolaou smear (Pap-smear) sampling and colposcopy were performed during the same procedure whenever required.

\section{Sample processing for DNA Extraction}

DNA extraction of the cervical specimens was carried out at National Aids Research Institute (NARI), Pune. Cervical lavage samples which were collected in PreservCyt $₫$ and stored at $-20^{\circ} \mathrm{C}$ were processed in a biosafety cabinet in a laboratory physically separated from where the PCR amplification was performed. DNA of both HPV and cellular, was released by lysing cervical cell specimens using lysis buffer supplied with the Roche Amplicor HPV kit under denaturing conditions at elevated temperatures in the presence of proteinase $K$ followed by DNA purification in columns with a silica-based membrane using vacuum processing.

\section{DNA Amplification}

All the pre and post DNA extraction processes were carried out in a separate rooms and cabinets at National Aids Research Institute (NARI), Pune which are at different spaces so as to avoid further errors due to contamination. Blank controls were included during the extraction process to monitor contamination and errors.

\section{Linear array HPV (RLA)}

All the extracted DNA samples were subjected to linear array genotyping assay (Roche Diagnostics, Indianapolis, IN, USA) for amplification and further identification of the genotype. The Linear array genotyping assay is based on PCR amplification of target DNA using HPV primers, hybridization of the amplified product to oligonucleotide probes and their detection by colorimetric reaction. Particularly, the master mix contains primers for the amplification of a 450-bp fragment of the L1 region of more than $37 \mathrm{HPV}$ genotypes and a 268-bp fragment of the human $\beta$ globin gene. The detection and genotype determination was performed using the denaturated amplified DNA and an array of oligonucleotide probes, located in the polymorphic region of $\mathrm{L} 1$ that permitted independent identification of individual HPV genotypes. Negative samples were included in each assay to establish the specificity of the test.

\section{Sample selection for testing with two different primers} Among the 214 women who attended Obstetrics \& Gynecology clinic 33 samples yielded positive results in Linear array genotype assay and these samples were selected to test for HPV-DNA by PCR using the different primers MY09/11 and G5/G6.

\section{DNA Amplification using MY09/11 and G5/G6 primers}

Two different pairs of oligonucleotides primers were used in this study to detect HPV in cervical samples that is MY09/MY11, G5/G6. In order to standardize the amount of material used equal volumes of DNA extract were used for PCR with two different primers. PCR reactions for both the primers were carried out separately by following the standardized protocol and also the manufacturer's instructions. 
The PCR amplification was carried out separately using MY09/11 and G5/G6 primers to amplify L1-region of HPV genome. In one set of PCR, Consensus primers MY09/11 were used, in a mix containing Taq DNA Polymerase Master Mix (QIAGEN囚), and 10 pmol of primers $\mathrm{PCO} / \mathrm{GH} 20$ for the simultaneous amplification of a $248 \mathrm{bp}$ product of the human $\beta$-globin housekeeping gene. Amplifications were performed with an initial denaturation step of $15 \mathrm{~min}$ at $95^{\circ} \mathrm{C}$, followed by 40 cycles $(1 \mathrm{~min}$ of denaturation at $94^{\circ} \mathrm{C}$, annealing at $55^{\circ} \mathrm{C} / 1 \mathrm{~min}$ and an extension step at $72^{\circ} \mathrm{C} / 5$ $\mathrm{min}$ ) and a final extension of $72^{\circ} \mathrm{C} / 10 \mathrm{~min}$.

In another set of PCR, G5/G6 primers were used, in a mix containing Taq DNA Polymerase Master Mix (QIAGEN®), and 10 pmol of primers PC04/GH20 for the simultaneous amplification of a $248 \mathrm{bp}$ product of the human $\beta$-globin housekeeping gene. Commercially available positive controls were used during the PCR assay. Amplifications were performed with an initial denaturation step of $15 \mathrm{~min}$ at $95^{\circ} \mathrm{C}$, followed by 40 cycles $\left(4^{\circ} \mathrm{C} / 1\right.$ min, $55^{\circ} \mathrm{C} / 1 \mathrm{~min}$ and $72^{\circ} \mathrm{C} / 1 \mathrm{~min}$ ) with a final extension of $72^{\circ} \mathrm{C} / 5$ min. Commercially available positive controls and water as a negative control for both the PCR reactions. After amplification the products were then visualized on $2 \%$ agarose gels containing 10 $\mu \mathrm{L}$ of ethidium bromide/100 $\mathrm{mL}$ agarose, under UV light.

Table 1: General primers sequences for HPV DNA detection

\begin{tabular}{lcc}
\hline Primer & Sequences* (5'-3') $^{\prime}$ & Size (bp) \\
\hline MY11 & GCMCAGGGWCATAAYAATGG & $\sim 450$ \\
MY 09 & CGTCCMARRGGAWACTGATC & \\
G5 & TTTGTTACTGTGGTAGATAC & $\sim 150$ \\
G6 & GAAAAATAAACTGTAAATCA & \\
\hline
\end{tabular}

\section{STATISTICAL ANALYSIS}

Mc Nemar test was performed to assess the difference between MY09/11 and G5/G6 primer sers with positivity of HPV DNA. The data were analysed by using SPSS software (Chicago, IL, USA), 20.0 version. The statistical significance was set at $5 \%$ level ( $p$ $<0.05)$.

Table 2: Percentage of DNA of HPV detection with oligonucleotide primers pairs

\begin{tabular}{lccc}
\hline HPV DNA detection & MY09/11 $(\mathrm{n}=33)$ & G5/ G6 $(\mathrm{n}=33)$ & P value \\
\hline Negative & 12 & 09 & 0.2500 \\
Positive & 21 & 24 & \\
\hline
\end{tabular}

Table 3: Comparison of G5/G6 and MY09/11 in assessment of HPV status

\begin{tabular}{clcccc}
\hline & Results & \multicolumn{4}{c}{ G5/G6 } \\
\cline { 3 - 6 } MY09/11 & & Positive & Negative & Total & $\%$ \\
& Positive & 21 & 0 & 21 & 63.64 \\
& Negative & 3 & 9 & 12 & 36.36 \\
& Total & 24 & 9 & 33 & 100.00 \\
& $\%$ & 72.73 & 27.27 & 100.00 & \\
\hline
\end{tabular}

Table 4: Sensitivity and specificity

\begin{tabular}{lc}
\hline Sensitivity & 87.50 \\
\hline Specificity & 100.00 \\
Positive predictive value & 100.00 \\
Negative predictive value & 75.00 \\
Disease prevalence & 0.73 \\
\hline
\end{tabular}

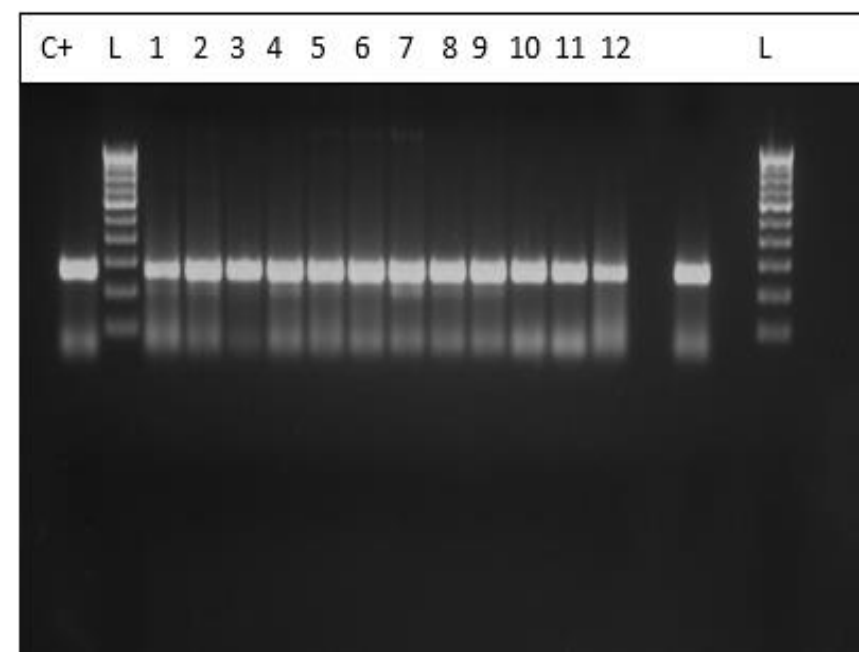

Figure 1: Agarose gel stained with blue green loading dye showing PCR electrophoretic profile using PCO3/PCO4 oligonucleotide primers for human ß-globin gene detection corresponding to $\sim 110 \mathrm{pb}$ PCR: polymerase chain reaction; HPV: human papillomavirus; L: ladder;

C+: positive control; C-: negative control. 


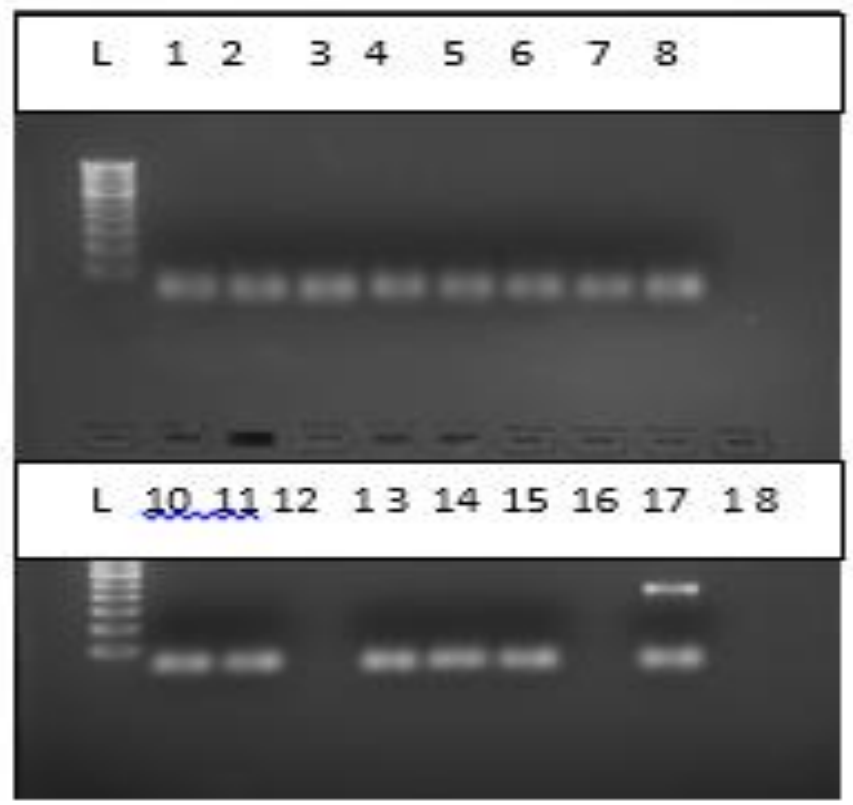

Figure 2: Agarose gel stained with blue green loading dye showing PCR electrophoretic profile using MY09/11 oligonucleotide primers for HPV DNA detection corresponding to $\sim 450 \mathrm{pb}$ PCR: polymerase chain reaction; HPV: human papillomavirus; L: ladder; C+: positive control; C-: negative control.

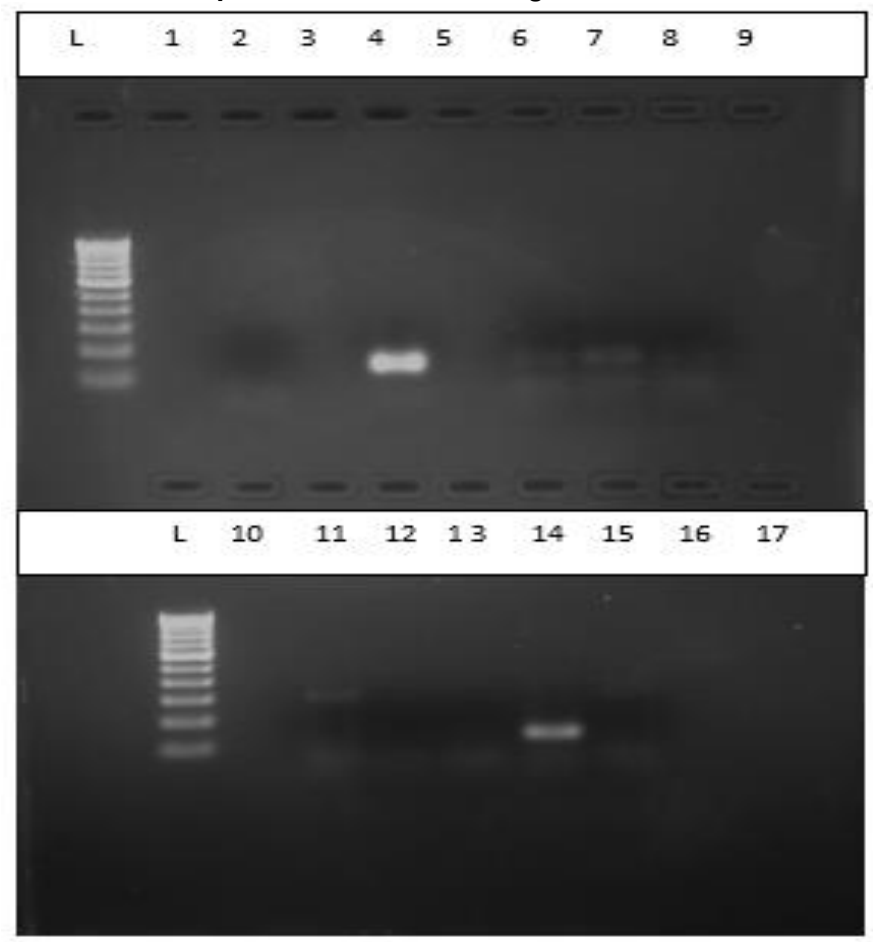

Figure 3: Agarose gel (1,5\%) stained with blue green loading dye showing PCR electrophoretic profile using G5/G6 oligonucleotide primers for HPV-DNA detection corresponding to $\sim 150 \mathrm{pb}$ PCR: polymerase chain reaction; HPV: human papillomavirus; L: ladder;

\section{RESULTS} C+: positive control; C-: negative control.
All 214 samples were amplified for HPV DNA and genotypes were identified by Linear array genotype assay (Roche Diagnostics, Indianapolis, IN, USA), which yielded high risk HPV genotypes in 33 samples.

Thirty three samples which were positive in Linear array genotype assay were evaluated by using two different oligonucleotide primers MY09/11 and G5/G6 by HPV-DNA analysis by PCR. HPV DNA was detected in $63.7 \%$ (21 of 33) and $72.73 \%$ (24 of 33) of the samples by using the MY-PCR and the G5/G6 -PCR primer sets, respectively. Among the $24 \mathrm{HPV}$-positive samples, 21 $(63.7 \%)$ were detected by one or both methods and $3(9.09 \%)$ were detected only by G5/G6 primer set. There was good agreement between the two PCR systems in the detection of HPV DNA. There was no statistical significance between the two oligonucleotides primers used in PCRs. The sensitivity and specificity in the detection of HPV DNA between two primer sets was found to be $87.50 \%$ and $100 \%$ respectively. The positive and negative predictive values are respectively $100 \%$ and $75 \%$. 


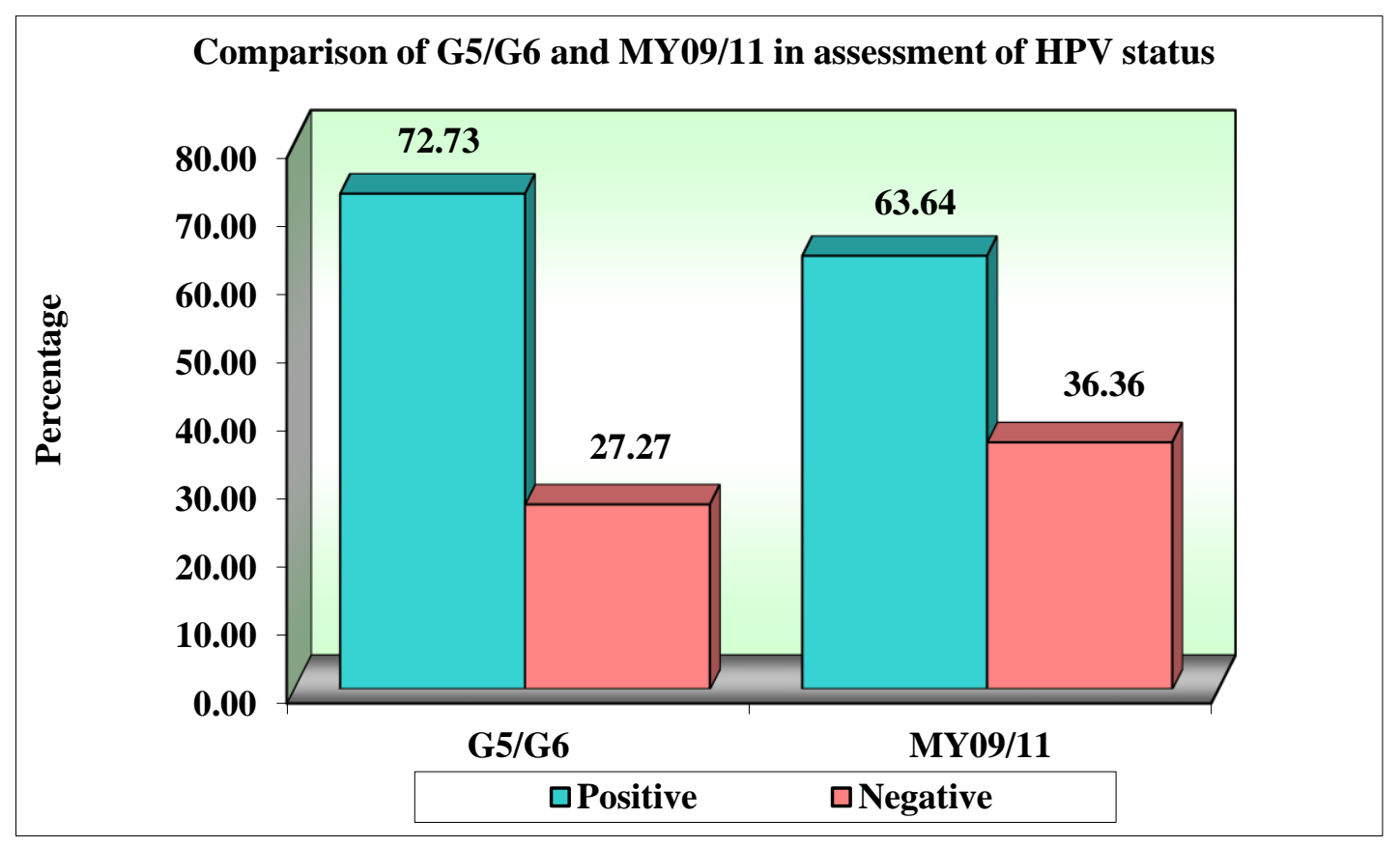

Figure 4: Comparison of G5/G6 and MY09/11 in assessment of HP status

\section{DISCUSSION}

Now a days PCR is most commonly used in clinical, research and diagnostic laboratories to detect HPV infections. For the L1 region, two oligonucleotides primers systems are commonly used: MY09/MY11 and G5/G6. Both of these primers detect a wide range of HPV DNA. Degenerated MY09/MY11 oligonucleotide primer uses annealing high temperature $\left(55^{\circ} \mathrm{C}\right)$ and can amplify multiple HPV infections.

However, G5/G6 oligonucleotide primer has lower annealing temperature $\left(42^{\circ} \mathrm{C}\right)$ compared to MY09/11 primer, allowing the best amplification by single genotype HPV infections ${ }^{23}$.

In our study we have compared the two major primer sets used for PCR amplification for HPV DNA in a group of positive samples obtained from Liner array assay results from cervicovaginal samples obtained from HIV infected women.

Each PCR method showed a high level of reproducibility when compared to itself, as previously demonstrated with the MY09/11 and $\mathrm{G} 5 / \mathrm{G} 6$ assays in different laboratories ${ }^{27}$.

In our study we observed a greater number of positive samples using G5/G6 oligonucleotides, when compared to MY09/MY11. However, there was no statistical difference between the two oligonucleotides used in PCRs $(p=0.2500)$ but clinical significance is seen since G5/G6 primer set detected 3 more samples as positive compared to 21 from MY09/11 primer set. Our results were similar to walboomers study and Remmerbach studies ${ }^{11,28}$.

According to Poljak et al. ${ }^{29}$ and Vince et al. ${ }^{30}$, one cannot rule out the possibility of false negative results in PCR due to low concentration of DNA in the clinical samples and the also due to the presence of PCR endogenous inhibitors or from faulty sample processing.

In a study by walboomers ${ }^{11}$, they compared the sensitivity of these oligonucleotides primers for PCR in cervical biopsies where the authors demonstrated that the two oligonucleotides primers used were equally sensitive, with a correlation of $98 \%$. Using G5/G6, the authors found HPV positivity of $95 \%$ with MY09/MY11 of $94 \%$. Qu et al. ${ }^{23}$, compared the detection rates of the same oligonucleotides primers used in our experiment (MY09/MY11 and G5/G6) in cervicovaginal washing sample, they found DNA of HPV in $45.5 \%$ and $42.8 \%$, respectively, with no statistical difference between the two oligonucleotides used in PCRs, only in the evaluation of HPV types detected by each pair of oligonucleotide, result similar to ours, which also showed no statistical difference.

Remmerbach et al. ${ }^{28}$, through oral mucosal smears analysis of patients suspected of carcinoma lesions, reported that HPV detection with G5/G6 oligonucleotides was higher than MY09/MY11 oligonucleotides.

\section{CONCLUSION}

Both MY09/MY11 and GP5/GP6 primer sets amplified a wide spectrum of HPV genotypes in cervicovaginal samples and detected similar results of HPV positivity but since G5/G6 primers detected additional 3 samples as positive our study suggests that more than one type of oligonucleotide primer should be used in clinical samples to increase the sensitivity in HPV detection.

\section{ACKNOWLEDGEMENTS}

We are grateful to National Aids Research Institute (NARI), Pune for helping in carrying out my study. Special thanks go to Dr. Arati Mane and Mrs. Linata Patil for supporting our study during processing and testing of samples at NARI, Pune.

\section{REFERENCES}

1. Ferlay J, Soerjomataram I, Ervik M, Dikshit R, Eser S, Mathers C, Rebelo M, Parkin DM, Forman D, Bray F. GLOBOCAN 2012 v1.2, Cancer Incidence and Mortality Worldwide: IARC CancerBase No. 11 [Internet]. Lyon, France: International Agency for Research on Cancer; 2013. Available from: http://globocan.iarc.fr. [Accessed on 13th January 2015]

2. Vaccine, Volume 24, Supplement 3, Pages S1-S264 (21 August 2006), HPV Vaccines and Screening in the Prevention of Cervical Cancer, Edited by F.X. Bosch, J. Cuzick, J.T. Schiller, G.P. Garnett and A. Meheus, E.L. Franco, T.C. Wright. 
3. Vaccine, Volume 26, Supplement 10, Pages K1-K94 (19 August 2008), Prevention of Cervical Cancer: Progress and Challenges on HPV Vaccination and Screening, Edited by FX Bosch, TC Wright, E Ferrer, N Munoz, EL Franco, R Herrero, L Bruni, SM Garland, J Cuzick, KS Louie and M Stanley

4. Vaccine Volume 30, Supplement 5, Pages F1-F202 (20 November 2012), Comprehensive Control of HPV Infections and Related Diseases, Edited by F.X. Bosch, T.R. Broker, M. Schiffman, J. Cuzick, C.J.L.M. Meijer, R. Sankaranarayanan, X. Castellsagué, J.J. Kim, M.A. Kane, M. Steben, L.A. Denny, M. Brotons and S. de Sanjosé 5. IARC Monographs 2007, Vol. 90, http://monographs.iarc.fr/ENG/Monographs/vol90/mono90.pdf.

[Accessed on: 26th November 2015]

6. Ghittoni, R; Accardi, R; Chiocca, S; Tommasino, M (2015), "Role of human papillomaviruses in carcinogenesis", ecancer 9 (526), doi:10.3332/ecancer.2015.526,PMC 4431404, PMID 25987895

7. Antonsson, A., O. Forslund, H. Ekberg, G. Sterner, and B. G. Hansson. 2000. The ubiquity and impressive genomic diversity of human skin papillomaviruses suggest a commensalic nature of these viruses. J. Virol. 74:11636-11641.

8. Division of STD Prevention (1999). Prevention of genital HPV infection and sequelae: report of an external consultants' meeting. Atlanta, GA: Centers for Disease Control and Prevention

9. Munoz, N., F. X. Bosch, S. de Sanjose, R. Herrero, X. Castellsague, K. V. Shah, P. J. Snijders, and C. J. Meijer. 2003. Epidemiologic classification of human papillomavirus types associated with cervical cancer. N. Engl. J. Med. 348:518-527.

10. Franco EL, Rohan TE, Villa LL. Epidemiologic evidence and human papillomavirus infection as a necessary cause of cervical cancer. J Natl Cancer Inst. 1999; 91: 506-11.

11. Walboomers JM, Jacobs MV, Manos MM, Bosch FX, Kummer JA, Shah KV, Snijders PJ, Peto J, Meijer CJ, Munoz N. Human papillomavirus is a necessary cause of invasive cervical cancer worldwide. J Pathol. 1999; 189: 12-9.

12. Walboomers, J. M., M. V. Jacobs, M. M. Manos, F. X. Bosch, J. A. Kummer, K. V. Shah, P. J. Snijders, J. Peto, C. J. Meijer, and N. Munoz. 1999. Human papillomavirus is a necessary cause of invasive cervical cancer worldwide. J. Pathol. 189:12-19.

13. Ellerbrock TV, Chiasson MA, Bush TJ, Sun XW, Sawo D, Brudney $\mathrm{K}$, Wright TC Jr. Incidence of cervical squamous intraepithelial lesions in HIV-infected women. JAMA 2000; 283: 1031-7.

14. Hawes SE, Critchlow CW, Faye Niang MA, Diouf MB, Diop A, Touré P, Aziz Kasse A, Dembele B, Salif Sow P, Coll-Seck AM, et al. Increased risk of high-grade cervical squamous intraepithelial lesions and invasive cervical cancer among African women with human immunodeficiency virus type 1 and 2 infections. J Infect Dis 2003; 188: 555-63.

15. Guiguet M, Boué F, Cadranel J, Lang JM, Rosenthal E, Costagliola D; Clinical Epidemiology Group of the FHDH-ANRS CO4 Cohort. Effect of immunodeficiency, HIV viral load, and antiretroviral therapy on the risk of individual malignancies (FHDH-ANRS CO4): a prospective cohort study. Lancet Oncol 2009; 10: 1152-9.

16. Abraham AG, D'Souza G, Jing Y, Gange SJ, Sterling TR, Silverberg MJ, Saag MS, Rourke SB, Rachlis A, Napravnik S, et al. Invasive cervical cancer risk among HIV-infected women: a North American multicohort collaboration prospective study. J Acquir Immune Defic Syndr 2013; 62: 405-13.

17. Lissouba P, Van de Perre P, Auvert B. Association of genital human papillomavirus infection with HIV acquisition: a systematic review and meta-analysis. Sex Transm Infect 2013; 89: 350-6.

18. Houlihan CF, Larke NL, Watson-Jones D, Smith-McCune KK, Shiboski S, Gravitt PE, Smith JS, Kuhn L, Wang C, Hayes R. Human papillomavirus infection and increased risk of HIV acquisition: a systematic review and meta-analysis. AIDS 2012; 26: 2211-22.

19.http://www.who.int/mediacentre/factsheets/fs380/en/ [Accessed on 07th July 2016]

20. Fernandes APM, Gonçalves MAG, Simões RT, Quintana SM, Duarte G, Donadi EA. Influência da infecção pelo HIV-1 sobre a presença do HPV em lesões do colo uterino. J Bras Doenças Sex Transm. 2004;16(1):21-25.

21. Gravitt PE, Peyton CL, Alessi TQ, Wheeler CM, Coutlée F, Hildesheim $A$ et al. Improved amplification of genital human papillomaviruses. J Clin Microbiol. 2000;38(1):357-361.

22. Choi YD, Jungc WW, Nama JH, Choi HS, Park CS. Detection of HPV genotypes in cervical lesions by the HPV DNA Chip and sequencing. Gynecol Oncol. 2005;98:369-375.

23. Qu W, Jian GG, Cruz Y, Chang CJ, Ho GYF, Klein RS et al. PCR Detection of Human Papillomavirus: Comparison between MY09/MY11 and GP51/GP61 Primer Systems. J Clin Microbiol. 1997;35(6):1304-10.

24. Karlsen, F., M. Kalantari, A. Jenkins, E. Pettersen, G. Kristensen, R. Holm, B. Johansson, and B. Hagmar. 1996. Use of multiple PCR primer sets for optimal detection of human papillomavirus. J. Clin. Microbiol. 34:2095- 2100

25. Smits, H. L., L. J. Bollen, A. H. S. P. Tjong, J. Vonk, J. Van Der Velden, F. J. Ten Kate, J. A. Kaan, B. W. Mol, and J. Ter Schegget. 1995. Intermethod variation in detection of human papillomavirus DNA in cervical smears. J. Clin. Microbiol. 33:2631-2636

26. Souza NST, Melo VH, Castro LFP. Diagnóstico da infecção pelo HPV em lesões do colo do útero em mulheres HIV+: acuidade da histopatologia. Rev Bras Ginecol Obstet. 2001;3(6):355-361.

27. Hsing, A., R. Burk, K.-L. Liaw, C.-J. Chen, T. Zhang, M. Schiffman, C. Greer, S.-L. You, C.-Y. Hsieh, T. Huang, T.-C. Wu, T. O'Leary, J. Seidman, and M. Manos. 1996. Interlaboratory agreement in a polymerase chain reaction-based human papillomavirus DNA assay. Cancer Epidemiol. Biomarkers Prev. 5:483-484.

28. Remmerbach, $T$ W. et al. PCR detection of human papillomavirus of the mucosa: comparison between MY09/MY11 and GP5+/6+ primer sets. J Clin Virol, v. 30, n. 4, p. 302-8, 2004.

29. Poljak, M. et al. Rapid extraction of DNA from archival clinical specimens: our experiences. Pflugers Arch, v. 439, n. 3, p. 42-4, 2000.

30. Vince, A et al. DNA extraction from archival giemsa-stained bonemarrow slides: comparison of six rapid methods. Br JHaematol, v. 101,n. 2, p. 349-51, 1998.

\section{Source of Support: Nil.}

\section{Conflict of Interest: None Declared.}

Copyright: (c) the author(s) and publisher. IJMRP is an official publication of Ibn Sina Academy of Medieval Medicine \& Sciences, registered in 2001 under Indian Trusts Act, 1882.

This is an open access article distributed under the terms of the Creative Commons Attribution Non-commercial License, which permits unrestricted non-commercial use, distribution, and reproduction in any medium, provided the original work is properly cited.

Cite this article as: Vinay. P. S, Chidanand Patil, Mahantesh Nagmoti, Anita Dalal, Shivalingappa Javali. Detection of HPV DNA Using MY09/MY11 and G5/G6 Primer Sets in HIV Positive Patients with Positive Linear Array Genotype Assay Results. Int J Med Res Prof. 2016; 2(5):22-27. 